\title{
The World's Hero: Gods and Archetypes in the Myth of the Superman
}

\author{
Rehuel Nikolai B. Soriano \\ Ateneo de Manila University \\ rehuel.soriano@obf.ateneo.edu
}

DOI: http://doi.org/ 10.36892/ijlls.v3i1.582

\begin{tabular}{|c|c|}
\hline $\begin{array}{l}\text { Received: } \\
\text { 04/01/2021 }\end{array}$ & \\
\hline $\begin{array}{l}\text { Accepted: } \\
06 / 03 / 2021\end{array}$ & $\begin{array}{l}\text { Superman, as a fictional character, is an amalgamation of the extra human } \\
\text { attributes of the heroes and gods that are read and seen in ancient narratives. } \\
\text { Specifically, it identifies the qualities of Superman as a superhero, determines } \\
\text { the parallelism that exists between these qualities of Superman and those of }\end{array}$ \\
\hline $\begin{array}{l}\text { Keywords: } \\
\text { Archetypes, } \\
\text { Literature, Myth, } \\
\text { Graphic Novels, } \\
\text { Film, Symbols, } \\
\text { Media, Superman, }\end{array}$ & $\begin{array}{l}\text { mythological and biblical personae, and establishes the similarity between the } \\
\text { scenes, situations, and events found in its mythos and those that are found in } \\
\text { archetypal narratives to vividly delineate his image as the world's superhero. } \\
\text { A content analysis of the text was primarily conducted to draw the structural } \\
\text { elements of its narrative. Since this study also assumes that literary texts may } \\
\text { be viewed outside of their aesthetic merits, an archetypal analysis is } \\
\text { subsequently implemented. Meanwhile, the theoretical foundation of this study } \\
\text { is predicated on the theory of Archetypes which assumes that literary texts are } \\
\text { based on and influenced by archaic structures manifested in the recurring } \\
\text { motifs, mythological counterparts, and parallelisms embedded in the story. As } \\
\text { stated in the results, it was determined that the mythos of Superman as a heroic } \\
\text { character is a reimagination and manifestation of mythological stories as } \\
\text { exemplified in the analyzed materials. Furthermore, it showed that he functions } \\
\text { as a custodian of several archetypal figures and with this, can be used as a } \\
\text { bridge in teaching traditional literature since he embodies a conglomeration of } \\
\text { several mythological characters. The materials analyzed in this study were } \\
\text { composed of eight graphic novels, six Hollywood films, and two animated } \\
\text { movies. }\end{array}$ \\
\hline
\end{tabular}

\section{INTRODUCTION}

\subsection{Myth and reality}

Since time immemorial, myth has been functioning as a schema of human behavior (Mayer, 2014). Unlike the brute animal that is guided by pure instinct, the recurrent patterns of legitimizing myths have been the driving force of human affairs giving him the advantage over the other species of this hostile planet (Hyers, 2006). For the moment, humans are victorious against the dangers of nature, subjugated it, and extracted order out of chaos (Peterson, 1999). As civilizations arose with their towering walls and imagined borders, culture emerged as a regulating force of society and protected its inhabitants from the threats of nature (Peterson, 1999). Ideologies too were formulated and became the base of several movements that shaped the course of history. These were the foundations of some historical figures guided by their 
dreams of a utopian state and quests for glory, they had achieved great feats and committed atrocities in the name of myth. While it is a grim reality that myth is being neglected by some because of its anachronistic nature, still, its value as representations of actions justify its existence and relevance. It is not that society's radical change makes myth something irrelevant, but what makes it unconnected with reality is the drastic changes that happened in its methods of delivery (Huppatz, 2011). If myths in the past were passed orally from one generation to another, then myths in the present time are formally being expressed through the media (Godawa, 2002). Currently, the irrational has no place in the current society for humans rely heavily on the promises of science (Peterson, 1999). While humanity's progress is being anchored towards its tenets, the attempts to unravel the questions of ultimate reality become an invisible roadmap of one's cosmos. In the name of objectivity and progress, a vital and fundamental construal of the world is being left out (Peterson, 1999). Through natural selection, humans have developed eyesight that can identify the only valid and finite interpretation of a given situation - a kind of interpretation that leads to one's survival (Williams, 2016). In this Darwinian sense, truth is abstracted out from the things that are left out. The result is that the material becomes synonymous with the objective and the potency of the immaterial (things that are left out) loses its explanatory power (Peterson, 1999). The failure of progressivism that is formally expressed through science, in satisfying the gaps it created, resulted in the construction of the postmodern mantra that there is an infinite number of interpretations. This gave way to multiple perspectives of reality where History became histories, Truth became truths, and the deferment of the final signified became its center. As a consequence, an event, situation, or text is described, evaluated, and justified within the confines of the cultures of the world. Having stated these series of claims, several issues may be raised. Why is it that despite our cultural idiosyncrasies common grounds still arise? Are there any universalities that function as a meta-narrative that hover over culture? Or everything is operating within the context of culture?

\subsection{Rise of the Superman}

Nietzche claims that the transcendent hero, in his quest for truth, must leave the role of a camel, assume the role of a lion, and devour the great dragon (der Braak, 2015). His work may be viewed as a promising work of individuality and originality, but, when archetypically analyzed, points to a collective primordial structure. For example, the ancient Mesopotamians tell a tale of a sea serpent named Tiamat who lost her husband and later was killed by the allseeing Marduk (Xiang, 2018). Meanwhile, the ancient Hebrews had their story of Yahweh defeating the Leviathan (Fox, 2012). And the Greeks also had their gaping void that gave birth to the first deities (Christopoulos, Levaniouk, and Karakantza, 2010). The myths themselves no matter how old they are and whichever culture they originated have been evidential to the existence of a parallel archetypal narrative (Mordern, 2016). This phenomenon can be seen in the mythos of Superman that appeared in the pages of comics amid the Great American Depression - a historic event that led to the birth of the Superhero which prompted the beginning of an explosion that would color popular culture for decades to come (Maslon and Kantor, 2013). He was the first character to fully embody the definition of the Superhero and prompted the repetition necessary for the emergence of a genre (Darowski, 2014). Eventually, his narrative was revealed through television and continuously being reinvented in the cinema 
as society's dynamic nature causes changes to our cultural values and beliefs (Teiwes, 2015). Hill (1992, as cited in Godawa, 2011) argues that while most people nowadays believe that they are modern-techno-secular citizens, they are still susceptible to myths. They have become modern worshippers that congregate at the cinematic temple with their ritual corns. They have become modern mythologies in the sense that their stories have also become conduits of the myths themselves evolving into unifying symbols (Peretti, 2017). Despite this, the genre is still being ignored by the scholarly community. It was even identified as one of the most underutilized works of literature because of its childish stigma (Kozlovic, 2012). However, Hubbard (2018) argues that the genre has already matured since "...comic book successes dictate that amplifying storyline to appeal to more age groups, will preserve box office success" (p. 27). She also claims that to satisfy its viewers, the characters must have a "...fully developed, matured story" (p. 24). It is within this perspective that this study is undertaken; that an investigation on how contemporary writers reinterpret traditional myths must be conducted.

\subsection{Statement of the problem}

In light of the foregoing, this study generally demonstrates the phenomenon of Superman as a conglomeration of extra-human attributes found in the heroes and gods depicted in ancient narratives. Specifically, it identifies the qualities of Superman as a superhero, determines the parallelism that exists between these qualities of Superman and those of mythological and biblical personae, and establishes the similarity between the scenes/situations/events and story of Superman and those that are found in archetypal narratives to vividly delineate the image of Superman as the world's superhero.

\subsection{Literature review}

Gang (2011) demonstrates the influence/transformation of behavioristic Psychology to/into New Criticism. He starts his essay with a description of the origins of close-reading and tracing it back from the works of the literary critic I.A. Richards in the 1920s. He claims that despite the continuous counterpoints of Brooks, Wimsatt, and Beardsley, the behavioristic poetics of Richards can still be found in some of the New Critical assumptions of poetry displayed in their writings such as Wrought Urn, Heresy of Paraphrase, and Intentional Fallacy. In this case, the text is viewed as a behavior rather than a mental state. Thus, when a text is closely read, the critic does not only conduct aesthetic assumptions but psychological assumptions are also carried out. Latham (2012) examines this aesthetic link between Greek myths and modern-day comic books using an aesthetic-rhetoric approach to visual arts with emphasis on Heracles and Perseus. Specifically, it tackles how superheroes are being drawn in modern comic books and how those artistic styles are influenced by statuesque depictions of Greek mythology. Moreover, Natale (2013) analyzes the changes in the physical presentation of several comic book superheroes. The study concluded that the bodies of superheroes have become far more sexualized, exaggerated, and unrealistic in recent years. The literature on the bodies of male and female bodybuilders revealed a connection to the hyper-embodiment of male and female superheroes which represent the ego ideal of western representations of perfect gendered bodies. The study concludes that contemporary comic books must shift from the modern age to the postmodern age to break out of their practices of reaffirming gender binaries. Koole (2013) demonstrates this by highlighting the significance of the superhero 
genre and the uniqueness of the superhero film. He claims that Superheroes clearly have mythological counterparts in which it relates their popular appeal to universal human motivations that stem from people's confrontation with existential realities. Moreover, the study discusses the recent trend towards the deconstruction of the superhero myth and considers the possible psychological ramifications of this trend. Furthermore, Arnaudo (2013) adds that the superhero genre is modern mythology for its episodic, symbolic, and encyclopedic nature presenting itself as an interlink of various narratives defining each other. This is popularly known as the universe or multiverse, a structure that connects a character's storyline to another character's mythos. In chapter one, he cites Richard Reynolds who labeled the comic book form as modern mythology. He claims that these superheroes are re-imaginations of ancient structures. Meaning, these modern characters are based and influenced by mythological figures equating Silver Surfer and Superman to Jesus as Christ figures. In chapter two, he explains that Superheroes are depicted primarily as protectors of mythic traditional values such as optimism, pragmatism, and individualism. They tend to be ethical and moral subtly promoting good over evil, right over wrong, and light over darkness. In chapter three, he analyzes the style and form of the medium utilizing Sergio Zatti's definition of epic which he justified with reference to the multiverse of $D C$ and Marvel superhero comic books, its archetypal equivalent, and episodic structure. Meanwhile, Kohut (2014) tackles superhero narratives and the evolution of the superhero genre. The study addresses the ethical questions of morality as seen in Superhero narratives. It is an exploration of the philosophical richness behind popular culture's phenomenon of superheroes. Several major philosophical themes, including the matters of identity, morality, and society are identified. The study claims that the parallelism between superhero stories and ancient mythologies shares the same societal functions. The genre defines a new category of literary characters, the superhero, as both an extension of the traditional conception of the hero character from ancient Greek mythology and an independent cultural category. Superhero narratives create consistent mythology of their own, addressing an equally wide range of topics for their readers to contemplate.

With this, the Superhero genre is a form of world literature for its creative prowess and universality. Cheah (2014) presents his conceptions of the world as the product of temporalization which constitutes the opening of a world. This formulation opposes the spatial description of the world and points out that it is not merely a custodian or container of things. He explained that time is a vital factor in creating worlds for before it can be considered as an objective world, it "must be". Here Cheah uses a phenomenological approach in his definition of the world and demonstrates the creative power of the conscious observing subject. He said that "world literature is not just a circulation of the works of different nations, but the result of active power and convention of world-making". With this, he also assigns the power of agency to world literature in which it can intervene in the worlding process as an active participant in the phenomena. However, Cheah fails to recognize that this active world creation phenomenon, ultimately, will manifest itself into actuality. And if this active world-making process has been in operation for millions of years, it means that the incorporation of such in the spatial landscape and archetypal landscape is possible (in a Darwinian sense). Jung (1981) identifies this force behind a text's worlding capacity. He argues that narratives are fundamentally based on and influenced by a primordial structure that are manifestations of the collective unconscious known as the archetypes. However, Jung's assertions are accused of being 
pseudoscientific because of their association with mysticism. With this, Gil (2018), distinguishes the conceptions of Carl Jung and Northrop Frye of archetypes. He qualifies that Jung's archetype is platonic and should not be confused with Frye's archetypal image which lies on the conscious part of the psyche. According to Jimenez (2020), archetypes reside within the imagination which is a creative function of consciousness that fuses the physical sensation with mental processes. Thus, Frye's take on the archetype is somehow a deviation from the Jungian conception. Moreover, myth is not solely confined within the boundaries of the individual for it has a sociological dimension as well. As literature, it also reflects society. Watt (2001) qualifies such a claim. He said that while it is true that literature functions as a mirror of the various features of life in society, yet, these extraliterary elements are not current at the time of writing. Literature in general, cannot be considered as a necessary and reliable reflection of the state of affairs. He claims that every individual is idiosyncratic and that an author, given his prejudices, may color events in his work and present these social events in a way that may favor his own biases. Thus, instead of reflecting society, literature may refract it.

By and large, numerous studies examine the aesthetic, psychological, and sociological tenets of the Superhero genre. However, there are no studies that deal with the conglomeration of mythological archetypes found in the character of Superman. This study satisfies this gap and provides a comprehensive description of the nature and phenomena of the character.

\subsection{Theoretical framework \& methodology}

The theoretical basis of the study is within the framework of what literary critics call the archetypal approach formulated by psychologists who established a reductionist-Jungian conception of literary texts. It approaches literature not through its artistic merits but its underlying archaic structures. The basic assumption is that literary works could be explained through the Archetypes which are platonic structures residing within the collective unconscious (Jung, 1981) It is the inherited part of the human psyche revealed through myths, religious beliefs, and dreams in the form of recurring images and figures (Frye, 2020). For these theorists, literary texts contain interrelated symbols including narrative forms which are matters constantly under revision (Gill, 2018). By applying the archetypal approach to the story of Superman, this study successfully extracted its predefined structure. These were used as tools to identify the parallelisms between the mythos of Superman with the stories of characters that can be found in ancient mythologies and biblical narratives. The specific methodological approach adopted in this study is content analysis which was undertaken within a precept in literary criticism that delineations and interpretations of fictional characters must not contradict the text being examined (Fitzpatrick, 2013) To accomplish this, the author conducted the following procedures; critical identification of relevant and vital literary texts, close-reading and close-watching of the identified materials, the establishment of archetypal parallelisms found in ancient mythologies and biblical narratives, and synthesis of mythical characters that point to Superman as the quintessential-world superhero.

\section{RESULTS \& DISCUSSION}




\subsection{The Pacifist, Marxist-Socialist, and the Man of Steel}

In 1938, comic book artists Joe Shuster and Jerry Siegel created arguably the most iconic comic book superhero of all time, Superman. He becomes one of the most recognizable characters in popular culture that made the public forget those who preceded him. Superman's height is six feet and three inches and weighs two hundred and twenty-five pounds. His hair is natural black and has a pair of blue eyes. He is always represented in the comics as a muscular man with a prominent square jawline. Originally, he wears a red trunk on top of his blue Kryptonian ceremonial suit with red boots and cape. In his new incarnations, slight changes were made. They removed the red trunks and made the color of his costume darker and grittier. Moreover, multiracial Supermen were created as the DC multiverse continuously expands. Though Superman in some of his storylines is portrayed as an embodiment of the Eisenhower era of conformity, his worldwide popularity releases the character from the monopoly of America resulting in the creation of his alternate incarnations. Some of them are the African American pacifist Val-Zod of Earth-2, The Chinese freedom fighter Kong Kenan of Prime Earth, and finally, the socialist Kal-L of the Red Son: Superman story arch characterized as the champion of the common worker who fights a never-ending battle for Stalin, socialism, and the international expansion of the Warsaw Pact. Though there are multiple versions of the character, still, all incarnations are based on a set of universal and overarching qualities and attributes. For example, Superman is always depicted as a strongman. Its creators explained that his strength is the result of his highly evolved Kryptonian physical structure. Furthermore, his strength is dependent on the amount of solar energy stored in his cells. He is commonly described as stronger than a locomotive and depicted as someone who can easily lift a weight of 200 quintillion tons (Morrison, 2005). In the New 52 series, his strength exceeds 5.972 sextillion metric tons which give him the capacity to move planets. Snyder's (2013) film Man of Steel shows Superman's strength as herculean as it is depicted in the oil spillage scene. Meanwhile, Jurgens, Simonson, Jones, Ordway, Kesel, Messner-Loebs, and Stem's (1993) graphic novel Death of Superman illustrates his strength as equal with the villain Doomsday.

Furthermore, Morrison's (2016) graphic novel Action Comics Vol 2 shows Superman's extraordinary eyes. His vision can detect electromagnetic energy in more than the normal visible spectrum. He can see through walls using his X-ray vision, see his enemies in pitch black using his infrared vision, analyze the subatomic particles of his surroundings through his microscopic vision, and gaze at the remains of a supernova light-years away through his telescopic vision. Chang, Register, and Burnett's (2012) animated film Superman vs. The Elite depicts Superman's capacity to shoot energy projectiles. In this movie, he uses his heat vision at the microscopic level lobotomizing Manchester Black. Meanwhile, Singer's (2006) film Superman Returns depicts Superman using a low-temperature-invisible-heat- vision to disintegrate the broken glasses from the destroyed buildings. In hot temperatures, heat vision is visually seen as a laser-like beam (Spengler and Lester, 1983). In some of his incarnations, he has the power to generate a devastating solar flare (Uwuigbe, 2015).

He can also run and fly faster than a locomotive (Crary, 2017). Millar's (2003) graphic novel Superman: Red Son describes him ten times faster than the speed of human thought as he plays chess with the Flash (Crary, 2017). In the 1940s, Superman was only able to jump with great distance thus the famous cartoon slogan "able to jump with tall buildings in a single 
bound". When the Fleisher Brothers find it too difficult to animate Superman jumping from one building to another, the company requested its publisher to change his attribute to flight. Burn's (2006) documentary Science of Superman demonstrates the mechanism behind this ability. It claims that he can manipulate gravitons which are hypothesized subatomic particles responsible for gravity.

He mastered two fictional Kryptonian martial arts, Torqasm-vo and Torqasm-rao which are martial arts similar to yoga and tai chi. It enables the user to reach a theta state in which the user can manipulate reality (Waid, 2003). He is also trained in boxing and learned multiple martial arts under Batman. Snyder's (2013) film Man of Steel shows that he has a dense molecular structure. He is immune to all types of extreme physical harm and his skin is impenetrable. Moreover, Morrison (2007) illustrated that his invulnerability is further enhanced by his solar aura in some of his incarnations. Maggin and Swan's (1985) version wears solar-powered armor that further enhances his invulnerability. Meanwhile, Morrison's (1998) version bathes in the sun for fifteen thousand years making his power levels infinite transforming his figure into an immortal radiant solar deity. Though all Kryptonians can absorb solar energy, Superman is more developed than his predecessors since he was exposed to sunlight at an incredibly young age.

\subsection{The messianic archetype}

Kozlovic (2002) stated that Superman's age was never mentioned in the movies to protect his identity. However, one can calculate his age since it was mentioned in the Fortress of Solitude scene that he was an eighteen-year-old teenager and twelve years later, flew out with a clear idea of his messianic mission (Kozlivic 2002). His Kryptonian name Kal-el means all that God is in the Hebrew language (Engle, 1987 as cited in Kozlovic, 2002). In the comics, his name means star child while his earth name Clark is an old English name meaning cleric. His earth surname Kent resembles the Hebrew kana k-n-t which means I have found a son (White, 2013). Kozlovic (2002) added that the "Jewish influence of Superman's name can also be detected in the suffix man which is common to many contemporary Jewish names..." (p.7) and that "the Hebrew origin of Super is Sopher in which the meaning is scribe" (p.7). Having said this, a conglomeration of Hebraic features can be synthesized pointing to the messianic archetype. In literary studies, the messianic archetype is described as someone who endures great sacrifices including death to save his people from an impending apocalypse. Superman exemplifies this description. He is an extra-terrestrial immigrant from the planet Krypton who is sent by his father Jor-el to Earth. He grew up in Smallville, Kansas, and is raised by his adoptive parents. Later on, he then left Smallville and traveled to the North Pole where the Fortress of Solitude is located. He then realized his purpose and finally returned to Metropolis (and eventually the world) to fulfill his destiny as its savior and champion. In comparison, Jesus' first home is in Nazareth and eventually left home to meditate in the wilderness (King James Bible, 1769/2017, Mark 1:12-13). After this stage of his life, he started his work of salvation at the age of thirty (King James Bible, 1769/2017, Luke 3:22). Eventually, he will return as the son of man with his father's glory (King James Bible, 1769/2017, Mathew 23:3132). Thus, both characters echo the characteristics of the Judeo-Christian messiah. They are both from a faraway land sent by their heavenly fathers to the world of ordinary men. Another 
parallelism is that both of them are depicted in the texts as ideal heroes. Jesus is depicted as the manifestation of the word or logos in John 1:1 (King James Bible, 1769/2017), "In the beginning was the Word, and the Word was with God, and the Word was God." By this means Jesus is from God. In John 8:42 (King James Bible, 1769/2017), "Jesus said unto them...for I proceeded forth and came from God". The God being referred to in this passage is in heaven (King James Bible, 1769/2017, Mathew 6:9), "After this manner, therefore, pray ye: Our Father which art in heaven". In other words, Jesus is described here as a divine being in the sense that he is the manifestation of the logos_—an archetypal hero that extracts order out of chaos (Peterson, 1999). He functions as a savior-messiah who dispels darkness through God's radiance as Hebrews 1:3 (King James Bible, 1769/2017) states, “..the radiance of God's glory and the exact representation of his being." By this means that he is an ideal - the perfect being. Similarly, Snyder's film Man of Steel depicts Superman as an embodiment of the Kryptonian race and an ideal to perfection (Snyder, Nolan, and Thomas, 2013). It states:

"You will give the people of Earth an ideal to strive towards. They will race behind you, they will stumble, they will fall. But in time, they will join you in the sun, Kal. In time, you will help them accomplish wonders."

Furthermore, Superman and Jesus are both in accord with their heavenly fathers (King James Bible, 1769/2017, John 10:30). Donner's (1978) film Superman shows Jor-El delivering his farewell message to his son, Kal-El. It says:

"You will travel far, my little Kal-El. But we will never leave you... even in the face of our death. The richness of our lives shall be yours. All that I have, all that I've learned, everything I feel... all this, and more, I... I bequeath you, my son. You will carry me inside you, all the days of your life. You will make my strength your own, and see my life through your eyes, as your life will be seen through mine. The son becomes the father, and the father the son. This is all I... all I can send you, Kal-El.”

Comparably, the speech resembles the content of John 3:16 (King James Bible, 1769, 2017), "For God so loved the world, that he gave his only begotten Son, that whosoever believeth in him should not perish, but have everlasting life."

In his other incarnations, Superman is being portrayed as a custodian of law and order as he condemns Lex Luthor for breaking the laws of nature when he genetically engineered a fetus (Furrie 1987). Similarly, in Mathews 5:7 (King James Bible, 1769, 2017), Jesus says, "Do not think that I have come to abolish the Law or the Prophets; I have not come to abolish them but to fulfill them" which also reflects Superman's dialogue contextually in Synder's (2013) film Man of Steel, "Do what you have to do, General". Comparably, this dialogue resembles Mark 12:17 (King James Bible, 1769, 2017) when Jesus showed obedience to the law in which it states, "And Jesus answering said unto them, render to Caesar the things that are Caesar's, and to God the things that are God's..." Coincidentally, Weldon (2013) added that Superman is also a metaphor of the Eisenhower-era of conformity. However, he is not a mere pawn of the government. He is not only known to fight for truth, justice, and the American way but also someone who is guided by morality. In other words, he upholds not only what the law says but also endorses the good. Meaning, he is a morally good Superhero. In the final scenes of 
Donner's (1978) film Superman, despite his father's commandment to not intervene with human history, he still intervened because he believed that it was the right thing to do (Donner and Spengler, 1978). He saved Lois from her death and reversed the earth's rotation which is a simplistic literary device that symbolically represents time travel. It says:

"Jor-El's voice: It is forbidden for you to interfere in human history.

Jonathan Kent's voice: One thing I do know son and that is you are here for a reason.

Jor-El's voice: It is forbidden for you...

Superman: looks down and makes up his mind and flies up and onwards as lightning flashes again."

Similarly, Jesus chose the higher good instead of following the law of Moses (King James Bible, 1769/2017, John 8:1). Thus, when both characters are faced to choose between the lawfully right or the greater good, both characters will choose the greater good.

Singer's (2006) film Superman Returns portrays Superman being stabbed by his archenemy Lex Luthor with a kryptonite knife that led to his coma and was revived on the third day. Snyder's (2016) film Batman vs Superman shows Superman performing a crucifix pose when he reenters the earth's atmosphere. Ross, Waid, and Klein's (2006) graphic novel Kingdom Come illustrates Superman carrying a large wood on his shoulders as an allusion to that Jewish carpenter. He is portrayed as the leader of the superheroes leading them to the final events of Armageddon to redeem humanity from its impending annihilation (Ross, Waid, and Klein, 2006). These narratives are direct allegories of the chronicles of Jesus. According to Mark 6:3 (King James Bible, 1769, 2017), Jesus is identified as a carpenter, "Isn't this the carpenter? Isn't this Mary's son and the brother of James, Joseph, Judas, and Simon?". He is also called the King of kings clothed with a robe dipped in blood who will rule his people with a rod of iron (King James Bible, 1769/2017, Revelation 19:13). Moreover, Jesus is known as the begotten son sent by the Father to redeem humanity (King James Bible, 1769/2017, John 3:16). Equally, Superman is the only son of Jor-El who was sent on a mission to save the people of earth (Clanton, 2017). While on a mission, both became conduits of truth. In John 14:6 (King James Bible, 1769/2017), Jesus introduced himself as the "...way and the truth". Meanwhile, Donner's (1978) film characterized Superman as a person who never lies. In addition, Superman's Kryptonian name is Kal-El. In Hebrew, el means god (Earnest, 1998). According to Kozlovic (2002), Kal bears a linguistic relation to the Hebrew guttural root hal which means all. Kal-El resembles Immanuel which is one of the many names given to Jesus (King James Bible, 1769/2017, Mathew 1:23). The official title of Jesus is the word Christ which means the anointed one (King James Bible, 1769/2017, Mathew 1:16). Being the anointed one had enabled Jesus to perform great miracles during his time. Coincidentally, the term Superman is also a title given by the people of Metropolis to $\mathrm{Kal}$ which is derived from the S-like symbol on his chest which also means hope (Snyder, 2013).

Aside from Jesus, Moses is also similar to Superman for both had special origins. They are both placed in a container, traveled through a sort of space (outer space and river space) to escape death, and adopted by a different family. Superman worked as a newspaper reporter (a 
modern-day scribe) while Moses delivered the ten commandments written in stone tablets. Superman used the name Clark Kent on his job to conceal his Kryptonian origins while Moses grew up as an Egyptian prince whose Jewish roots are hidden. In connection, the creators of Superman were both Jews. Harrington and Winokuer (2020) claim that its creators were afraid of being unemployed during the depression, and, reading of the oppression and slaughter of oppressed Jews in Nazi Germany, the Superman character emerged from their great urge to help the downtrodden masses. Another piece of evidence that links Superman to the biblical character Moses is presented in his origin story arc. In this narrative, Krypton was on the verge of destruction when he was rocketed on earth (Gordon, 2017). His escape pod has Kryptonian inscriptions similar to hieroglyphics which is a clear allusion to Moses. Before his voyage, JorEl inserted a tablet-like device containing Krypton's accumulated knowledge (Waid, 2016). This can be interpreted as a homage to the Ten Commandments engraved in stone tablets. To support this, Kara (Supergirl) was also sent to protect Superman from danger but her escape pod was knocked out by Krypton's explosion delaying her arrival on earth. When Superman landed, he was found by an American midwestern family. He was raised as their son and taught the responsibilities of being an extraordinary individual (O'Roark, 2018). He started as a vigilante superhero at the start of his career and eventually transformed into the archetypal liberator of Metropolis from its corrupt officials (Morrison, 2012; Scott, 2014 ). In Morrison's (2012) graphic novel Action Comics Vol 1, fate leads Superman to the location of his trademark suit, wore it, and fights Brainiac. Superman emerges victoriously and realizes that his purpose is to protect the earth's inhabitants. Similarly, the biblical prophet Moses was put in a wicker basket and placed in the Nile River (Carr, 2014). His sister followed him from afar before the Pharoah's daughter found Moses (King James Bible, 1769/2017, Exodus 2:4). He was then raised as an Egyptian prince and eventually became the deliverer of the ancient Israelites from the bondage of Egypt (King James Bible, 1769/2017, Exodus 2:1-9).

\subsection{The mythological deity archetype}

Superman's physique was influenced by Schuster's infatuation with bodybuildinglarge and round deltoids, thick saucer-like pectoral muscles, and torso that narrowed to the waist in a drastic V shape (Weldon, 2013). Donner's (1978) film Superman, portray's him as over six feet tall and weighs around two hundred twenty-five pounds. Superman's symmetrical eyebrows, blue eyes, prominent jawline, defined cheekbones, and cleft chin are the key aspects of his perfect visage. Though virtually invulnerable, he still wears a blue Kryptonian ceremonial armor that symbolizes the fixed firmament of the heavens (Kozlovic, 2002). Morrison (2012) claims that his strength is superhuman and exceeds the force of two hundred quintillion tons. Meanwhile, Crary (2017) estimates that his strength exceeds 5.972 sextillion metric tons making him one of the strongest superheroes. He is also invulnerable to nearly any type of physical attack (Stern, Rude, and Milgron, 1999). Comparably, the Greek demigod Heracles is portrayed traditionally as a muscular strongman, stands four cubits and one foot, and typically portrayed as a monster-slaying hero (Grimal and Kershaw, 2012; O'Brien, 2014; Stanfford, 2017). In popular media, he possesses extra-human strength and is considered the champion of the Greco-Roman world. At the beginning of his twelve labors, he had to fight the Nemean lion with only a wooden club as his weapon. After he killed the beast, he transformed its skin into an armor (Cotterell, 2006). 
Furthermore, Superman's Kryptonian name Kal-El means star child (White, 2013). Coincidentally, it mirrors the name Samson which means Sun (Campbell, 2015). Likewise, Samson falls under the strongman archetype (King James Bible, 1769/2017, Judges 13:1-31). $\mathrm{He}$ is traditionally depicted as a dashing strongman, long-haired and muscular. Samson also had a special weapon - a donkey jawbone. With this single weapon, he was credited with remarkable exploits - the slaying of a lion and moving the gates of Gaza. However, he fell in love with Delilah who beguiled him into revealing the secret of his strength - his long Nazirite hair (King James Bible, 1769/2017, Judges 16:4-30). However, some bible scholars contest that the real source of Samson's strength lies not in the hair but in the God of the hair. It is when Samson revealed to Delilah the symbol of his dedication to God-the source of his strength. In other words, the shearing of his hair is also a metaphor for his disobedience. Then like Esau, Samson lost his powers because he despised his birthright (Cohen, 1970). In comparison, Donner's (1980) film Superman 2 depicts Superman giving up his birthright. For the sake of Lois Lane, he abandoned his duty and decided to live the life of a mortal being.

Norse Mythology had also its imprint. Thor is known as the thunder god and the son of Odin. He is portrayed in popular media as a muscular-bearded hero with lightning-like eyes (Lindemans, 2006). Sturluson (2007) depicts Thor as a dying hero after he toppled the giant serpent Jormugandr but retreats and falls dead suffocated by the serpent's venom. In addition, the epic of Beowulf has the same characterization and narrative structure. Beowulf's physical presence is striking enough to draw attention. Hammet (2015) characterizes him as a war leader with a glistening mail shirt. Pragmatically, he can be seen as an alien in the sense that he is someone who had traveled from a distant land. He crossed the seas and reached the land of the Danes who comes to the aid of King Hrothgar to settle affairs with Grendel - the demon. In comparison, Jurgen's (1993) graphic novel The Death of Superman depicts the triumph of Superman over the Kryptonian monster Doomsday. Also, Snyder's (2016) film Batman vs Superman depicts him defeating Doomsday. Though he is presented as a victorious hero in this story arc, however, he still dies at the end of the story and eventually will be resurrected after a couple of days.

As earlier mentioned, Superman has a bioelectric aura. His cells can radiate and create an invisible force field that engulfs his whole body making his skin impenetrable (Beatty, 2002). It is for this reason Superman is also called the Man of Steel. This echoes the juggernaut of Hebrew mythology - the Golem. According to Jewish Folklore, the Golem is an artificially created rock/clay humanoid creature that protects the defenseless Jews against their enemies (Dennis, 2007). Furthermore, this description of the Golem can also be read in Rosenberg's (1909) collection of interrelated stories. It also depicts the Golem as the protector of the defenseless Jews. Similarly, the Norse hero Siegfried has also impenetrable skin except for a spot covered by a fallen leaf when he bathed in the blood of a dragon that he slew (Spencer and Milton, 2013). In Greek mythology, Achilles is also portrayed as a handsome-fair-haired hero with flashing eyes and a powerful voice (Grimal and Kershaw, 1991). His mother made him nearly invulnerable by dipping his whole body in the River Styx except for his heel-his kryptonite. 
As previously discussed, Superman derives his power from the sun. In this regard, Morrison (2012) depicts Superman as a sun-God with the capability of reigniting a dying sun. In Philippine Mythology, Apolaki holds dominion over the sun (Jocano, 1969). He is also considered to be the counterpart of the Kapampangan supreme deity, Aring Sinukuan. Meanwhile in Greek Mythology, Helios whom the Romans called Sol Invictus is often viewed as a mighty charioteer with gleaming horses who soared the sky from east to west. When the night falls, Helios crossed back to the east by floating in a golden cup on the stream of the ocean which is thought to encircle the flat earth. He represents the unconquered sun. For the ancient Greeks, Helios is omnipresent for he is associated with the rays of the sun which can illuminate the vastness of the world. Thus, both gods and humans called on him as a witness to various events or oaths sworn. His characterization in legends is portrayed as someone with a beardless and handsome face, a purplish robe, and wears a golden aureole. Similarly in Persian Mythology, Mithra resembles Superman. As mentioned earlier, Kal-El means star child which is a homage to the famous Mithraic saying, "I am a star which goes with thee and shines out of the depths". Here Mithra is depicted as a golden-flaming star-deity who is believed in Persian folklore as the center of the universe (Cirlot, 2006). In Egyptian Mythology, Horus is imagined as a falcon with a golden head (another recurring color) whose wings are the sky, the right eye is the sun, and the left eye is the moon (Hart, 1986). Like Superman, Horus has the power of flight. He is also associated with gold and shines like the sun.

\section{CONCLUSION}

The phenomena of Superman have been demonstrated as a conglomeration of several mythical characters. His extra-human qualities, messianic missions, missionary attributes, messianic image, mystic names, and mythological counterparts were concluded as the bases of the Superman mythos. Furthermore, two general archetypes have been identified. These are the Messianic Archetype and Mythical Deity Archetype. Each general archetype contained two sub-archetypes through which the characterization of Superman was equated with their images. These have been found as manifestations of recurring archetypal forms across world mythologies which served as evidence to the mythos of Superman as a representation of man's experienced realities. Specifically, these were the Judeo-Christian Messiah, the Hebrew Deliver, the Strong and Invulnerable Hero, and the Solar God. Moreover, it has been analyzed that the mysticism behind the names and titles of Superman contained religious undertones. As a form of media text, the character of Superman has undergone modifications and developed into a psychologically complex narrative compared to its predecessors. Moreover, what makes his narrative popular is its capacity to provide pre-conceived expectations which are prejudices and biases caused by archetypal structures. These structures have been found as structurally similar to what the mythologist Joseph Campbell called call narrative. With this, further investigation regarding the structure of its narratives is highly recommended. Finally, the study showed that Archetypal Criticism is an effective tool in reducing a literary character into its most basic foundation. It is an effective way of determining and analyzing literary works whether they are new creations, modifications, or reincarnations of primeval a priori structures. 


\section{REFERENCES}

Avery-Natale, E. (2013). An analysis of embodiment among six superheroes in DC Comics. Social Thought \& Research: A Continuation of the Mid-American Review of Sociology, 71-106.

Beatty, S. (2002). Superman: The Ultimate Guide to the Man of Steel. DK Pub.

Blas, T. (2018). Loki: God of Mischief.

Carr, D. M. (2014). Chapter Six: The Story of Moses. In Holy Resilience (pp. 110-127). Yale University Press.

Cheah, P. (2014). World against globe: Toward a normative conception of world literature. New Literary History, 45(3), 303-329.

Christopoulos, M., Levaniouk, O., \& Karakantza, E. D. (Eds.). (2010). Light and darkness in ancient Greek myth and religion (pp. 66-67). Lanham, MD: Lexington Books.

Cirlot, J. C. (2006). Dictionary of symbols. Routledge.

Clanton Jr, D. W. (2017). 1. The Origin (s) of Superman: Reimagining Religion in the Man of Steel. In Religion and Popular Culture in America, Third Edition (pp. 33-50). University of California Press.

Cohen, G. G. (1970). Samson and Hercules: A Comparison between the Feats of Samson and the Labours of Hercules.

Darowski, J. J. (2014). The superhero narrative and the Graphic novel. Critical insights: the Graphic novel, 3-16.

Dennis, G. W. (2007). The encyclopedia of Jewish myth, magic and mysticism. Woodbury, MN: Llewellyn Publications.

Dobson, D. (2005). Archetypal literary theory in the postmodern era. Journal of Jungian Scholarly Studies, 1.

Engle, G. (1992). What makes Superman so darned American? Popular culture: An introductory text, 314-43.

Fox, M. (2012). Behemoth and Leviathan. Biblica, 93(2), 261-267. Retrieved May 4, 2021, from http://www.jstor.org/stable/42615102

Frye, N. (2020). Anatomy of criticism: Four essays (Vol. 70). Princeton University Press.

Furie, S. (Director). (1987). Superman IV: The Quest for Peace. Warner Bros.

Gang, J. (2011). Behaviorism and the beginnings of close reading. ELH, 78(1), 1-25.

Gill, G. R. (2018). Archetypal Criticism: Jung and Frye. A Companion to Literary Theory, 396.

Godawa, B. (2009). Hollywood worldviews: Watching films with wisdom and discernment. InterVarsity Press.

Gordon, I. (2017). Superman: The persistence of an American icon. Rutgers University Press. 
Grimal, P., Kershaw, S., \& Maxwell-Hyslop, A. R. (1991). The Penguin dictionary of classical mythology. Penguin books.

Hammet, S. (2015). The Men about Town: The Characterization and Socialization of the Medieval Hero. Retrieved from Hanover College History Department website: https://history.hanover.edu/hhr/hhr4-4.html

Harrington, J. A., \& Winokuer, H. R. (2020). 2 And Then Came Superman. Superhero Grief: The Transformative Power of Loss, 2.

Hubbard, A. E. (2018). Stagnant Supers: Amplifying the Superhero Genre Through Novelistic Maturity.

Huppatz, D. J. (2011). Roland Barthes, Mythologies. Design and Culture, 3(1), 85-100.

Hyers, L. L. (2006). Myths used to legitimize the exploitation of animals: An application of social dominance theory. Anthrozoös, 19(3), 194-210.

Jurgens, D. (1993). The Death of Superman (B. Breeding, Illus.) DC Comics.

Jung, C. G. (2014). The archetypes and the collective unconscious. Routledge.

Klein, E. D., Rabin, C., \& Sarel, B. (1998). A comprehensive etymological dictionary of the Hebrew language for readers of English. Jerusalem: Karta.

Kohut, M. (2014). Superheroes: The Philosophy Behind Modern Myth. Unpublished Diploma Thesis, Masaryk University Faculty of Arts, Masaryk.

Koole, S. L., Fockenberg, D., Tops, M., \& Schneider, I. K. (2013). The Birth and Death of the Superhero Film. In Death in Classic and Contemporary Film (pp. 135-150). Palgrave Macmillan, New York.

Kozlovic, A. K. (2002). Superman as Christ-figure: The American pop culture movie Messiah. Journal of Religion \& Film, 6(1), 5.

Kozlovic, A. K. (2002). The holy, non-Christic biblical subtexts in Superman: The Movie (1978) and Superman II (1981). Journal of Religion \& Film, 6(2), 5.

Latham, A. S. (2012). Comic Books vs. Greek Mythology: The Ultimate Crossover for the Classical Scholar.

Mayer, F. W. (2014). Narrative Politics: Stories and collective action. Oxford University Press, USA.

Maslon, L., \& Kantor, M. (2013). Superheroes!: Capes, cowls, and the creation of comic book culture. Crown Archetype.

Mersch, D. (2009). 'There are, indeed, things that cannot be put into words. Wittgenstein's Ethics of Showing. Search of Meaning: Ludwig Wittgenstein on Ethics, Mysticism and Religion, 25-50.

Morden, M. (2016). Anatomy of the national myth: Archetypes and narrative in the study of nationalism. Nations and Nationalism, 22(3), 447-464.

Morrison, G. (2011). Supergods: What masked vigilantes, miraculous mutants, and a sun god from Smallville can teach us about being human. Random House. 
Morrison, G. (2004). JLA: One million (V. Semeiks, Illus.) DC Comics.

Morrison, G. (2012). Superman-Action Comics: Volume 1 (R. Morales, R. Kubert, Illus.) DC Comics.

O'Brien, D. (2014). Classical Masculinity and the Spectacular Body on Film: the mighty sons of Hercules. Springer.

O'Roark, B. (2018). Truth, Justice and the Economic Way. Superheroes and Economics: The Shadowy World of Capes, Masks and Invisible Hands.

Peretti, D. (2017). Superman in Myth and Folklore. Jackson: University Press of Mississippi.

Scott, K. (2014). No Guru, No Method, No Teacher: "Grant Morrison" and Grant Morrison.

Spencer, S., \& Millington, B. (2013). Wagner's Ring of the Nibelung: a companion. Thames \& Hudson.

Stern, R., Rude, S., \& Milgrom, A. (1999). The Incredible Hulk vs. Superman: Double lives New York, N.Y: Marvel Comics Group.

Stafford, E. (2017). Hercules' Choice: Virtue, Vice and the Hero of the Twentieth-Century Screen. In The Reception of Ancient Virtues and Vices in Modern Popular Culture (pp. 140-166). Brill.

Sturluson, S. (2007). The Younger Edda. BiblioBazaar, LLC.

Donner, R. (Director). (1978). Superman. Warner Bros.

Donner, R (Director). (1980). Superman 2. Warner Bros.

Teiwes, J. P. (2015). Crisis of infinite intertexts! Continuity as adaptation in the Superman multimedia franchise (Doctoral dissertation).

Watt, I. (2001). The rise of the novel. Univ of California Press.

Waid, M., Yu, L. F., Alanguilan, G., \& McCaig, D. (2016). Superman Birthright.

Waid, M., Ross, A., \& Klein, T. (2006). Kingdom Come. New York: DC Comics

Williams, David. (2015). Light and the evolution of vision. Eye (London, England). 30. 10.1038/eye.2015.220.

Xiang, Z. (2018). Below Either/Or: Rereading Femininity and Monstrosity Inside Enuma Elish. Feminist Theology, 26, 115 - 132.

Young-Eisendrath, P., \& Dawson, T. (Eds.). (2008). The Cambridge Companion to Jung. Cambridge University Press.

\section{AUTHORS' BIO}

Rehuel Nikolai B. Soriano is a full-time lecturer at the Department of English \& Humanities, Central Luzon State University, Philippines. He is currently taking his Ph.D. degree in Language and Literature at the Ateneo de Manila University with "Literature \& Mythology" as his area of concentration. His research interests are Jungian Archetypes, World Mythologies, and Game Studies. 